\title{
Comparative evaluation of the efficacy and safety of Ormeloxifene and combined oral contraceptives in dysfunctional uterine bleeding
}

\author{
Goel J.K. ${ }^{1}$, Agrawal V. ${ }^{2}$, Agrawal N. ${ }^{3}$, Sah S. ${ }^{4}$ \\ ${ }^{1}$ Dr. J.K. Goel, Professor and HOD, ${ }^{2}$ Dr. Vartika Agrawal, Senior Resident, ${ }^{3}$ Dr. Namita Agrawal, Professor, ${ }^{4}$ Dr. S. Sah, \\ Associate Professor, all authors are affiliated with Department of Obstetrics and Gynaecology, SRMS IMS, Bhojipura, \\ Uttar Pradesh, India.
}

Corresponding Author: Dr. Vartika Agrawal, Senior Resident, Department of Obstetrics and Gynaecology, SRMS IMS, Bhojipura, Uttar Pradesh, India. E-mail: vartika110@gmail.com

\begin{abstract}
Introduction: Dysfunctional Uterine Bleeding (DUB) is an abnormal uterine bleeding, in the absence of any organic, systemic or iatrogenic cause. Pharmacological treatment options available are combined oral contraceptive pills, progestogens, danazol, gonadotrophin releasing hormone $(\mathrm{GnRH})$ agonists, SERMs, prostaglandin synthetase inhibitor, anti-fibrinolytics and ethamsylate. The purpose of the study was to evaluate the efficacy and safety of Ormeloxifene and compare it to combined oral contraceptive pills (OCPs) in dysfunctional uterine bleeding. Method: Hundred women aged 20-50 years presenting with DUB were randomly allocated to two groups of 50 each. Group A were given Ormeloxifene tablet $60 \mathrm{mg}$ twice a week for 12 weeks, followed by $60 \mathrm{mg}$ once a week for 12 weeks. Group B were given OCPs containing 30 microgram Ethinyloestradiol and 150 microgram Levonorgestrel from day 1 to day 21 st of the menstrual cycle for 6 cycles. The outcome was studied by assessment of menstrual blood loss by Pictorial Blood loss Assessment Chart (PBAC) score, $\mathrm{Hb}$ level in $\mathrm{g} / \mathrm{dl}$, endometrial thickness in mm, patient's level of satisfaction and any drug side effects at the end of 6 months. Results: The reduction in mean PBAC score with Ormeloxifene (330 to 2.8) was significantly more than with oral contraceptive pills $(317$ to 74$)$ at 6 months $(\mathrm{P}<0.001)$. In both the groups mean hemoglobin level increased but rise in $\mathrm{Hb}$ in group $\mathrm{A}(1.5 \mathrm{~g} / \mathrm{dl})$ was more as compared to the rise in $\mathrm{Hb}$ in group $\mathrm{B}(1.2$ $\mathrm{g} / \mathrm{dl})$. The mean endometrial thickness decreased in both the groups but the decrease in group A (9.6 mm to $8.4 \mathrm{~mm}) \mathrm{was}$ not statistically significant as compared to the decrease in group B $(9.8 \mathrm{~mm}$ to $6.4 \mathrm{~mm})$. The side effects were minimal in both the groups. $22 \%$ patients with Ormeloxifene and $10 \%$ with oral contraceptive pills were highly satisfied with their treatment. Conclusion: Ormeloxifene is effective in control of DUB and can be used as an alternative to OCP for treatment of DUB with possibly minimal side effects and better dosage compliance.
\end{abstract}

Keywords: Ormeloxifene, Combined Oral Contraceptives, Dysfunctional uterine bleeding

\section{Introduction}

AUB in reproductive age women leads to one third of outpatient visits in gynecology OPD and this proportion increases to more than two third in peri- and postmenopausal age group [1]. It is defined as any bleeding that does not correspond with the frequency (about 28 days with a range from 21-35 days), duration (2-6 days), amount $(20-80 \mathrm{ml})$ and regularity of blood flow of normal menstrual cycle [2]. Hence, it is a symptom and not a disease. Dysfunctional uterine bleeding (DUB) is a state of abnormal uterine bleeding without any clinically detectable pelvic, systemic or iatrogenic cause

Manuscript received: $8^{\text {th }}$ October 2019

Reviewed: $18^{\text {th }}$ October 2019

Author Corrected: $26^{\text {th }}$ October 2019

Accepted for Publication: $31^{\text {st }}$ October 2019 in absence of pregnancy [3]. It can affect any woman from menarche to menopause, occurring more commonly at extremes of reproductive age when the function of HPO axis is either immature or starts ceasing and becomes irregular [4].

The choice of treatment depends on the cause, age, severity of bleeding, fertility status, need for contraception, and the treatment available at the center. Medical management has always been the first therapeutic option in patients of DUB. Pharmacological management can be hormonal or non-hormonal. Nonhormonal drugs like NSAIDs, ethamsylate and antifibrinolytics have also been found to be effective especially for short term management. Hormonal agents 


\section{Original Research Article}

include oestrogens, progesterones, combination of the two, androgens, danazol, GnRH agonists and SERMS (Selective Estrogen Receptor Modulators) [5]. Ormeloxifene is a third generation SERM and best known as a non-hormonal, non-steroidal oral contraceptive. Chemically it is trans-7 methoxy-2, 2dimethyl-3-phenyl-chroman-4-yl phenoxy ethyl pyrrolidine.

It blocks the cytosol receptor by its competitive binding over estradiol and causes asynchrony in the menstrual cycle between ovulation and the development of uterine lining. It antagonizes the effect of estrogen on uterine and breast tissue but is agonistic in its effect on vagina, bone, cardiovascular and central nervous system [6]. Combined oral contraceptives (COCs) produce first proliferation and then secretory changes in the endometrium similar to that during normal cycle and thus reestablishes predictable bleeding patterns, decrease menstrual flow significantly, and lower the risk of iron deficiency anemia.

Their mode of action in patients with DUB is endometrial atrophy. There may also be diminished prostaglandin synthesis \& decreased endometrial fibrinolysis [7].

\section{Materials and Methods}

Type of study: Prospective study

Study design: The present study consisted of 100 women aged 20-50 years presenting with Dysfunctional Uterine Bleeding at SRMS Institute of Medical Sciences, Bareilly from November 2016 to June 2018.

Sampling: Patients were randomly divided into two groups (Group A and Group B) of 50 each.

Group A were given Ormeloxifene tablet $60 \mathrm{mg}$ twice a week for 12 weeks, followed by $60 \mathrm{mg}$ once a week for 12 weeks.

Group B were given OCPs containing 30 microgram ethinylestradiol and 150 microgram levonorgestrel from day 1 to day 21 st of the menstrual cycle for 6 cycles.

\section{Inclusion criteria}

Patients aged 20-50 years

Patients reported with Dysfunctional Uterine Bleeding.

\section{Exclusion criteria}

Pregnancy- Patients with bleeding disorders, cardiac disorders, liver dysfunctions, migraine renal diseases.

Lactating women in first 6 months of post-natal period were excluded from the study.

Ethical consideration: Ethical approval was taken from the institutional ethical committee

The patients were asked to maintain a menstrual diary recording the days of bleeding, number of sanitary pads used, degree of soiling of each pad, number and size of clots passed, episodes of bleeding, the presence of menstrual cramps and other symptoms experienced.

Scoring system: Objective assessment of menstrual blood loss was done by Pictorial Blood loss Assessment Chart (PBAC).

A PBAC score $\geq 100$ indicates a menstrual blood loss $\geq 80 \mathrm{ml}$ and is considered diagnostic for menorrhagia.

During the treatment period, each patient will be followed-up after 3 months and 6 months of treatment. The outcome was studied by assessment of menstrual blood loss by PBAC score, Hb level in g/dl, endometrial thickness in mm, patient's level of satisfaction and any drug side effects.

Statistical analysis: Results were evaluated by mean, standard deviation and statistical significance was derived by 'p' value calculated by Student's t test and Chi-Square test. 
Table-1: PBAC scoring system [8]

\begin{tabular}{|l|c|}
\hline Pads & 1 \\
\hline Mildly soiled & 5 \\
\hline Moderately soiled & 20 \\
\hline Saturated & \\
\hline Clots & 1 \\
\hline Small (smaller than a rupee coin) & 5 \\
\hline Large (larger than a rupee coin) & \\
\hline
\end{tabular}

\section{Results}

The profile of patients of both the groups was represented in Table 2, which included the mean age, marital status, and parity. The difference in the mean age, marital status, and parity between study population of both groups was not significant. Table 1 aided in further distribution of cases in both the groups.

Table-2: Patient profile

\begin{tabular}{|c|c|c|}
\hline Parameter & Group A & Group B \\
\hline Mean age (years) & 34.8 & 31.9 \\
\hline Marital status & 45 & 41 \\
\hline Married & 5 & 9 \\
\hline Unmarried & \multicolumn{2}{|c|}{} \\
\hline Parity & 36 & 31 \\
\hline Multipara & 8 & 10 \\
\hline Nullipara & \multicolumn{2}{|c|}{} \\
\hline
\end{tabular}

In group $\mathrm{A}$ and group $\mathrm{B}$, distributions of cases were done in accordance to the symptoms observed in pre and post treatment. The symptoms were pre-established. Significant improvement was observed in cases with Dysmenorrhea, regularity of menstrual cycle, amount of flow, and duration of bleeding whereas the mean cycle length was $27.78 \pm 2.26$ after 6 months in the post-treatment group A and 27.38 \pm 1.59 after 6 months in the post treatment group B. (Table 3).

Table-3: Distribution of cases according to symptoms (pre and post treatment) in group A.

\begin{tabular}{|c|c|c|c|c|c|}
\hline & $\begin{array}{c}\text { Pre- } \\
\text { treatment }\end{array}$ & \multicolumn{4}{|c|}{ Post treatment } \\
\hline & & $\begin{array}{l}\text { After } 3 \\
\text { months }\end{array}$ & $\begin{array}{c}\text { Percentage } \\
\text { improvement }\end{array}$ & After 6 months & $\begin{array}{c}\text { Percentage } \\
\text { improvement }\end{array}$ \\
\hline \multicolumn{6}{|l|}{ Dysmenorrhea } \\
\hline Present & $16(32 \%)$ & $4(8 \%)$ & \multirow{2}{*}{$76 \%$} & - & \multirow{2}{*}{$100 \%$} \\
\hline Absent & $34(68 \%)$ & $46(92 \%)$ & & $50(100 \%)$ & \\
\hline \multicolumn{6}{|l|}{ Regularity } \\
\hline \multirow{2}{*}{ Regular } & \multirow{2}{*}{$38(76 \%)$} & Am-7 (14\%) & \multirow{4}{*}{$100 \%$} & Am-12 (24\%) & \multirow{4}{*}{$100 \%$} \\
\hline & & Reg-31 (62\%) & & Reg-26 (52\%) & \\
\hline \multirow{2}{*}{ Irregular } & \multirow{2}{*}{$12(24 \%)$} & Am-3 (6\%) & & Am-7 (14\%) & \\
\hline & & $\operatorname{Reg}-9(18 \%)$ & & Reg-5 (10\%) & \\
\hline \multicolumn{6}{|l|}{ Amount of flow } \\
\hline$>100$ PBAC & $50(100 \%)$ & $10(20 \%)$ & \multirow{2}{*}{$80 \%$} & - & \multirow{2}{*}{$100 \%$} \\
\hline$<100$ PBAC & - & $40(80 \%)$ & & $50(100 \%)$ & \\
\hline \multicolumn{6}{|l|}{ Duration of bleeding } \\
\hline$>5$ days & $44(88 \%)$ & $8(16 \%)$ & \multirow{2}{*}{$81 \%$} & - & \multirow{2}{*}{$100 \%$} \\
\hline$<5$ days & $6(12 \%)$ & $42(84 \%)$ & & $50(100 \%)$ & \\
\hline Mean cycle length & $26.51 \pm 2.08$ & $27.06 \pm 2.59$ & & $27.78 \pm 2.26$ & \\
\hline
\end{tabular}


Original Research Article

Table-4: Distribution of cases according to symptoms (pre and post treatment) in group B.

\begin{tabular}{|c|c|c|c|c|c|}
\hline & Pretreatment & \multicolumn{4}{|c|}{ Post treatment } \\
\hline & & After 3 months & $\begin{array}{c}\text { Percentage } \\
\text { improvement }\end{array}$ & $\begin{array}{l}\text { After } 6 \\
\text { months }\end{array}$ & $\begin{array}{c}\text { Percentage } \\
\text { improvement }\end{array}$ \\
\hline \multicolumn{6}{|l|}{ Dysmenorrhea } \\
\hline Present & $16(32 \%)$ & $5(10 \%)$ & \multirow[b]{2}{*}{$68.75 \%$} & - & \multirow[b]{2}{*}{$100 \%$} \\
\hline Absent & $34(68 \%)$ & $45(90 \%)$ & & $\begin{array}{c}50 \\
(100 \%)\end{array}$ & \\
\hline \multicolumn{6}{|l|}{ Regularity } \\
\hline \multirow{2}{*}{ Regular } & \multirow{2}{*}{$36(72 \%)$} & Am-1 (2\%) & \multirow{4}{*}{$100 \%$} & Am-2 (4\%) & \multirow{4}{*}{$100 \%$} \\
\hline & & Reg- $35(70 \%)$ & & Reg-34 (68\%) & \\
\hline \multirow{2}{*}{ Irregular } & \multirow{2}{*}{$14(28 \%)$} & Am- 0 & & Am- $1(2 \%)$ & \\
\hline & & Reg- $14(28 \%)$ & & Reg-13 (26\%) & \\
\hline \multicolumn{6}{|c|}{ Amount of flow } \\
\hline$>100$ PBAC & $49(98 \%)$ & $33(66 \%)$ & \multirow{2}{*}{$34.6 \%$} & $2(4 \%)$ & \multirow{2}{*}{$97.9 \%$} \\
\hline$<100$ PBAC & $1(2 \%)$ & $17(34 \%)$ & & $48(96 \%)$ & \\
\hline \multicolumn{6}{|l|}{$\begin{array}{l}\text { Duration of } \\
\text { bleeding }\end{array}$} \\
\hline$>5$ days & $40(80 \%)$ & $9(18 \%)$ & \multirow{2}{*}{$77.5 \%$} & - & \multirow{2}{*}{$100 \%$} \\
\hline$<5$ days & $10(20 \%)$ & $41(82 \%)$ & & $50(100 \%)$ & \\
\hline $\begin{array}{c}\text { Mean cycle } \\
\text { length }\end{array}$ & $25.92 \pm 2.34$ & $27.78 \pm 2.26$ & & $27.38 \pm 1.59$ & \\
\hline
\end{tabular}

In the present study, mean PBAC score during pretreatment cycle was 324.6 and 317.4 in group A and B respectively which was statistically non-significant $(\mathrm{p}>0.05)$. There was a significant reduction from its pretreatment level to 97.4 after 3 months and further to 36.2 after 6 months with a p value of $<0.001$ in group A. Similarly, in group B, there was a marked reduction to 153.2 after 3 months and further to 67.9 after 6 months which was also statistically significant with a $\mathrm{p}$ value of $<0.001$. Also, the difference between the mean PBAC score after 6 months in group A and group B was statistically significant ( $\mathrm{p}$ value $<0.001$ ) as the decrease in PBAC score in group A was more as compared to group B (Table 5).

Table-5: Comparison of outcomes between Group A and B.

\begin{tabular}{|l|c|c|c|c|c|c|}
\hline & Group A & & Group B & & \\
\hline Outcome & Pretreatment & $\begin{array}{c}\text { Post } \\
\text { treatment }\end{array}$ & P value & Pretreatment & $\begin{array}{c}\text { Post } \\
\text { treatment }\end{array}$ & P value \\
\hline Mean PBAC & 324.6 & 36 & $<0.001$ & 317.4 & 67 & $<0.001$ \\
\hline $\begin{array}{l}\text { Mean hemoglobin } \\
\text { (g/dl) }\end{array}$ & 8.9 & 10.4 & $<0.01$ & 8.8 & 9.9 & $<0.01$ \\
\hline $\begin{array}{l}\text { Mean endometrial } \\
\text { thickness (mm) }\end{array}$ & 9.6 & 8.4 & $>0.01$ & 9.8 & 6.4 & $<0.01$ \\
\hline
\end{tabular}

In Table 6, distribution of cases from both the groups based on the side effects reported and the level of satisfaction post treatment is observed. The only side effect observed in Group A was of GI disturbances, which comprised of $2 \%$ of the study population from Group A, whereas in Group B, along with GI disturbances, problems related to weight gain after 3 months $(2 \%)$ and 6 months $(8 \%)$ were reported along with headache in $2 \%$ of study population. The level of satisfaction from both groups was also observed. High level of satisfaction in group A was observed after 3 months (6\%) and 6 months (22\%), whereas high level of satisfaction observed in group B was $10 \%$ after 6 months of treatment. Only $12 \%$ of patients in group A reported poor level of satisfaction while $22 \%$ of study population reported poor level of satisfaction in group B after 3 months of treatment respectively. 
Original Research Article

Table-6: Distribution of cases according to side effects and level of satisfaction post treatment between group $A$ and group $B$

\begin{tabular}{|c|c|c|c|c|}
\hline & \multicolumn{2}{|c|}{ Group A $(n=50)$} & \multicolumn{2}{|c|}{ Group B $(n=50)$} \\
\hline & After 3 months & After 6 months & After 3 months & After 6 months \\
\hline \multicolumn{5}{|l|}{ Side effects } \\
\hline GI symptoms & $1(2 \%)$ & - & $9(18 \%)$ & $5(10 \%)$ \\
\hline Weight gain & - & - & $1(2 \%)$ & $4(8 \%)$ \\
\hline Headache & - & - & $1(2 \%)$ & - \\
\hline \multicolumn{5}{|l|}{$\begin{array}{c}\text { Level of } \\
\text { satisfaction }\end{array}$} \\
\hline Highly & $3(6 \%)$ & $11(22 \%)$ & - & $5(10 \%)$ \\
\hline Satisfied & $41(82 \%)$ & $39(78 \%)$ & $39(78 \%)$ & $45(90 \%)$ \\
\hline Poorly & $6(12 \%)$ & - & $11(22 \%)$ & - \\
\hline
\end{tabular}

\section{Discussion}

Wide varieties of treatment modalities are available for treating DUB, from medical therapy to minimally invasive surgery in the form of transcervical resection of the endometrium and thermal ablation to conventional hysterectomy.However, medical treatment should be the preferred modality of treatment when possible. Medical management of DUB is a challenging task with wide variations in the available drugs prescribed. Biswas et al in his study showed a significant reduction of median PBAC score from 272 in pretreatment cycles to 107.8 in post treatment cycles that are statistically significant, correlating well with the present study [9].

In the present study, hemoglobin level was measured before commencement of therapy and after completion of treatment. In group $\mathrm{A}$, improvement in mean hemoglobin level was $1.5 \mathrm{~g} / \mathrm{dl}$ ( $\mathrm{Hb}$ pre and post were 8.9 and $10.4 \mathrm{~g} / \mathrm{dl}$, respectively) and in group B was $\mathrm{g} / \mathrm{dl}$ ( $\mathrm{Hb}$ pre and post were 8.8 and $9.9 \mathrm{~g} / \mathrm{dl}$ respectively). Majority of patients had moderate anemia when enlisted into the study as defined by WHO (haemoglobin $<12$ $\mathrm{gm} / \mathrm{dl}$ ) i.e. $78 \%$ patients in group A and $82 \%$ patients in group B. After 6 months of treatment, only $64 \%$ patients had moderate anemia and the rest had mild anemia. Similarly, in group B, after 6 months, $84 \%$ had moderate anemia.

Khare et al also demonstrated that mean hemoglobin level after treatment improved from $7.0 \mathrm{gm} \%$, to 10.1 in Ormeloxifene group, whereas in OCP group from 7.2 gm $\%$ to $9.5 \mathrm{gm} \%$ [10]. Mean endometrial thickness at the beginning of treatment was $9.6 \mathrm{~mm}$ which reduced to $8.4 \mathrm{~mm}$ after 6 months in group A showing a nonsignificant reduction of only $1.2 \mathrm{~mm}$ from its pretreatment level. In group B, mean endometrial thickness was $9.8 \mathrm{~mm}$ which reduced to $6.4 \mathrm{~mm}$ after 6 months showing a significant reduction of $3.4 \mathrm{~mm}$ from its pretreatment level. Grover $\mathrm{S}$ et al also observed an increase in endometrial thickness in 3 patients $(13.6 \%)$ out of which 2 underwent hysterectomy and 50\% showed a decrease in endometrial thickness by 1 to 2 $\mathrm{mm}$ [11]. In the present study, in group A, 6\% patients were highly satisfied and $12 \%$ patients were poorly satisfied after 3 months whereas no patient was highly satisfied and $22 \%$ were poorly satisfied after 3 months in group B. After 6 months, maximum number of patients were satisfied in both the groups, none were poorly satisfied and $22 \%$ were highly satisfied in group A whereas only $10 \%$ were highly satisfied in group B.

Mandal et al observed that $11.11 \%$ of patients in ORM group and $14.71 \%$ of patients in OCP group were poorly satisfied [12].

In the present study, only $2 \%$ patients had gastrointestinal symptoms after 3 months in group A and no other adverse effect was seen. In group B, $18 \%$ had gastrointestinal symptoms such as nausea, vomiting and abdominal pain after 3 months which reduced to $10 \%$ after 6 months and $2 \%$ had weight gain after 3 months which increased to $8 \%$ after 6 months. $2 \%$ patients complained of headache after 3 months which subsided after 6 months follow up. No other side effect was observed.

Khare et al observed nausea, headache and weight gain in few patients of combined contraceptive pills and oligomenorrhea and amenorrhea in the Ormeloxifene group of patients [10]. The present study had a limitation in terms of study population included in the study. This was a very small study and larger randomized trials are needed to compare the two drugs for medical management of DUB. 


\section{Conclusion}

It was observed that Ormeloxifene and COC's are both effective for the treatment of DUB as evident by control of menorrhagia, increased haemoglobin concentration and reduced endometrial thickness as well as patient's satisfaction level. However, Ormeloxifene is more effective in reducing the amount of blood loss and improving hemoglobin level as compared to COCs. It is better tolerated, with convenient dose schedule and has lesser side effects as compared to combined oral contraceptives.

\section{What the study adds to the existing knowledge?}

The present study attempts to establish the efficacy of Ormeloxifene in the treatment of DUB, the comparative analysis was made against Combined oral contraceptives. With the observations obtained from the limited number of study population, it might be assumed that Ormeloxifene might be a far better option in the treatment of DUB as compared to combined oral contraceptives.

\section{Author's contribution}

Dr. J.K. Goel: Manuscript preparation

Dr. Vartika Agrawal: Concept, study design

Dr. Namita Agrawal: Statistical analysis

Dr. S Sah: Manuscript preparation

Funding: No funding sources

Conflict of interest: None declared

Ethical Approval: This study was approved by the Institutional Ethics Committee

\section{References}

1. Munro MG. Abnormal uterine bleeding in the reproductive years. Part II-medical management. J Am Assoc Gynecol Laparoscop. 2000;7(1):17-32.

2. Hoffman BL, Schorge JO, Schaffer JI, Halvorson M, Bradshaw KD, Gray F (Eds) Abnormal uterine bleeding. In: Schorge JD editor. Williams Gynaecology, 2nd ed. New York: McGraw-Hill;2003. p.219.
3. Konar H. Abnormal menstrual bleeding. D.C Dutta's Textbook of Gynaecology. 6th edition. New Delhi: Jaypee Brothers Medical Publishers; 2014:180.

4. Frick KD, Clark MA, Steinwachs DM, Langenberg P, Stovall D, Munro MG, et al. STOP-DUB Research Group. Financial and quality-of-life burden of dysfunctional uterine bleeding among women agreeing to obtain surgical treatment. Womens Health Issues. 2009; 19 (1): 70-78. doi:https://doi.org/10.1016/j.whi. 2008. 07.002 .

5. Masand D, Gupta S, Patel J. To Observe Effect of Ormeloxifene in Medical Management of Dysfunctional Uterine Bleeding. J Evol Med Dental Sci.2015;4(4): 587-597. doi: 10.14260/jemds/2015/87

6. Schorge OJ, Schaffer IJ. Abnormal uterine bleeding. Williams Gynecology: Chapter 8;186.

7. Irvine GA, Cameron IT. Medical management of Dysfunctional uterine bleeding.Best pract Res Clin Obstet Gynaecol. 1999;13(2):189-202.

8. Higham JM, O'Brien PMS, Shaw RW. Assessment of menstrual blood loss using a pictorial chart. $\mathrm{Br} \mathrm{J}$ Obstet Gynaecol. 1990; 97(8):734-739.

9. Biswas SC, Shaha SK, et al. Ormeloxifene a selective estrogen receptor modulator, for the treatment of dysfunctional uterine bleeding. J Obstet Gynaecol Ind. 2004; 54(1):56-59.

10. Khare V, Ghosh G, Patil P, Nagar N. Ormeloxifen HCL vs Combined Oral contraceptive Pill in Treatment of DUB. J Evol Med Dent Sci. 2014;3(4):1026-1033. doi: $10.14260 /$ jemds/2014/1941.

11. Grover - Panda SN. Ormeloxifene a new treatment modality in dysfunctional uterine bleeding. Guest Lecture in 45th All India Congress of Obstetrics and Gynaecology. 9th Jan.2002.

12. Mandal D, Parmanik S,Surana S et al. Comparative study of low-dose oral contraceptive pill and ormeloxifene in the treatment of dysfunctional uterine bleeding. Int J Health Allied Sci.2014;3(4):225-231. doi: $10.4103 / 2278-344 X .143056$.

\section{How to cite this article?}

Goel J.K, Agrawal V, Agrawal N, Sah S. Comparative evaluation of the efficacy and safety of Ormeloxifene and combined oral contraceptives in dysfunctional uterine bleeding. Obs Rev: J obstet Gynecol 2019;5(4):197-202. doi:10. 17511/joog.2019.i04.04. 